\title{
The Development of Pocketbook as an Accounting Teaching Material
}

\author{
Naomi Fahma \\ Master of Educational Technology \\ Sebelas Maret University \\ Surakarta-Indonesia \\ naomifahma07@gmail.com
}

\author{
Nunuk Suryani \\ Master of Educational Technology \\ Sebelas Maret University \\ Surakarta-Indonesia \\ nunuk_suryani_uns@yahoo.com
}

Akhmad Arif Musadad

Master of Educational Technology

Sebelas Maret University

Surakarta-Indonesia

arif_mussadad_fkip@yahoo.co.id

\begin{abstract}
Teaching materials are important for education implementation in schools. A teacher is required to create innovative and creative teaching materials that suit students' needs, so that the learning process becomes interesting and fun. This study is aimed at developing an eligible teaching material in the form of an Accounting pocketbook and revealing the impact of the use of the Accounting pocketbook on students' motivation to study. ADDIE was used as the development method in this study. The stages conducted in this study were analysis, design, development, implementation, and evaluation. This study used nontest method as the data collection technique with questionnaire and interview as the instruments. The data analysis techniques used in this research were descriptive quantitative methods. The results of this research show that using the Accounting pocketbook as the Accounting teaching material in XI Social class at Senior High Schools scores $\mathbf{9 1 . 3 \%}$ from media experts I, $\mathbf{9 2 . 0} \%$ from media experts II, $\mathbf{9 0 . 3 4 \%}$ from material experts I, and $91.30 \%$ of material experts II. Thus, it can be concluded that pocketbook products accounting teaching material is suitable for use in XI Social Class at Senior High Schools.
\end{abstract}

Keywords—teaching material; pocketbook; learning motivation

\section{INTRODUCTION}

In general, education is a communication process which includes the transformation of knowledge, values and skills, both within and outside the life-long educational institutions from generation to generation. This is in line with of Jerald [1] who says that education has played important roles creating human resources with certain qualifications for each generation. Such qualifications are usually needed by the generation in order to survive in the society where they live. In the 21st century today, the qualification that should be owned by human resources has shifted from simple cognitive skills toward more complex cognitive skills.

Learning is an effort exerted deliberately by educators to convey science, as well as to organize and create environmental systems with various methods, so that learners can perform learning activities effectively and efficiently with optimal results. As stated in the government regulation [2], learning is "the process of interaction among learners, between learners and educators, and learning resources to a learning environment."

A learning strategy is one of the factors that need to be considered by teachers or educators in their learning process. It consists of: (1) learning organizing strategy, (2) learning delivery strategy, and (3) learning management strategy [3]. The example of the second strategy, the learning delivery strategy, concerns the use of eligible teaching materials during the learning process.

Teaching materials are important for the implementation of education in schools. Through it, teachers will find it easier to implement the learning process, and students will be more helpful and find it easy to study. Teaching materials can be created in various forms based on their needs and characteristics to be presented [4]. Hadar [5] explores how textbooks function in education. It asked whether opportunities provided in textbooks to engage in tasks demanding different levels of understanding correlate with students' achievements for tasks demanding equivalent levels of understanding on a standardized exam.

In fact, most teachers have been using instant conventional teaching materials, and they do not even do any effort to plan, prepare, and arrange the teaching materials by themselves. An interesting, effective, and fun learning process cannot be created by only using the instant learning materials. On the 
contrary, a teacher is required to be creative in arranging innovative, varied, interesting, and eligible teaching materials that suit students' needs to create an interesting and fun learning process.

The use of teaching materials in high schools is still limited to the buku paket (instant teaching books), LKS (Students' Activity Sheets), and questions given by teachers. The buku paket sometimes seems less interesting to be used as a teaching material for students because of its less attractive appearance; sentences are too long; and the students feel that the book's size is less practical. These points make them less interested in reading and studying the book. In addition, they do not have other reference books that can help them to learn independently, except the buku paket and LKS.

Based on the above explanation, an innovative, creative, supportive and attractive teaching material needs to be developed. One alternative is to develop a supporting material in the form of a pocketbook. A pocketbook is a small-sized book that can be pocketed and practical to carry and read. This is in line with the thought by Khulafa [6] regarding a small pocketbook that can be placed into the pocket and easily carried anywhere, with short description reading using attractive fonts and backgrounds. The presentation of the pocketbook uses many pictures and colors to exhibit an interesting look. Accounting material that is considered complicated will be easily understood by students because the display of books made in accordance with the characteristics of students. Ease of understanding the material will bring about the motivation to succeed.

\section{RESEARCH METHODS}

The development model used in this study was ADDIE proposed by Molenda [7, p. 1]. It consists of five stages: (1) Analysis, (2) Design, (3) Development, (4) Implementation, and (5) Evaluation.

The subjects in this study were 29 students of XI Social class at Senior High Schools. The obtained data in this study were quantitative data as the primary data and qualitative data in the form of respondents' suggestions. The data provided an overview of the quality of the developed Accounting pocketbook. 1) The data from media experts were in the form of product quality seen from the aspect of visual media display. 2) The data from material experts were in the form of product quality seen from material aspects and teaching design. 3) The data from the respondents i.e. the XI Social class students were in the form of assessment of the product quality seen from the aspects of visual media display, material, and teaching design.

There were three data collection instruments used in this study i.e. (1) the validation instrument, (2) teachers' and students' response questionnaire and (3) the effectiveness of the instrument, a validated questionnaire of pocketbook assessment. The data collection techniques used in this study were questionnaires and interviews. The data were analyzed by using a descriptive quantitative statistic. The data collection instrument used was that of a questionnaire. The questionnaire from the media expert was analyzed by using a descriptive quantitative method. The percentage was obtained based on the calculation of scores on the Likert Scale with the range from 1 to 5 assessment with the description: 1) 1 represents very less category, 2) 2 represents less category, 3) 3 represents enough category 4) 4 represents good category, and 5) 5 represents a very good category.

\section{FINDINGS AND DISCUSSIONS}

The development process used in this study consists of 5 stages i.e. analysis, design, development, implementation, and evaluation.

\section{A. Analysis}

The analysis stage comprises the analysis of teaching materials and needs. The results show as follows:

\section{1) Teaching Materials Analysis}

Teaching materials used in XI Social class are in the form of Accounting LKS for high schools. It only contains summaries of materials with an illustrated look of a colorless journal table. The weakness is that the content is not explained in detail, for instance, the lack of the steps in financial recording in the journal, and it also does not provide additional information related to the Accounting cycle to provide more information.

\section{2) The Analysis of Needs}

The analysis of needs is conducted by examining the students' characteristics from the results of interviews with accounting teachers who have known their characteristics well. The results of the analysis are observed by taking samples in 29 XI Social class students. The general characteristic of XI Social class at high schools is that the students are 16 to 17 years old. According to Piaget, at the age of 11 years and above (the formal stage of operation) children have grown up, in the sense that they have the ability to coordinate simultaneously realized by the sequential use of their cognitive ability, namely using the hypothesis and principles of learning independently.

The problems expressed by the students based on the results of interviews on teaching materials is that they use an LKS which contains a less detailed summary of material, less interesting exercises because of its common appearance i.e. fill in the blanks and the use of opaque paper. In addition, the LKS size tends to be large, and they thus find it difficult to carry it anywhere. They want a more practical and easier book to use when studying wherever and whenever, and they also want a more complete material book that can make them easier to understand.

One of the criteria of good learning resources is the learning resource that can motivate students to study the subjects by providing interesting images, as well as cleaner and more colorful paper, allowing teachers to stimulate the learners to study in the learning program. 


\section{B. Design}

The design stage is to design a Pocketbook that matches the title of the Pocketbook that has been formulated and in accordance with the learning objectives to achieve. The purpose of the design stage is to design the product based on the analysis results. However, before designing the product there are things to be done including:

- collecting necessary materials such as drawings, tables and references,

- developing tests and evaluations, and

- drafting a Pocketbook (an initial product).

The program used to make a Pocketbook layout design is the Corel Draw X7 program. The size of the developed Pocketbook is $10 \mathrm{~cm} \times 13 \mathrm{~cm}$ and the thickness reaches 70 pages. The Pocket Books are printed in the form of books in general to make them more comfortable to read.

\section{Development}

At the development stage, the product is made based on the design, being validated and developed based on validators' suggestions. After the product is made, the product eligibility assessment is conducted by two validators, before being implemented in high schools.

The developed pocketbook measures $10 \mathrm{~cm} \times 13 \mathrm{~cm}$. The components or formats of the developed pocketbook include:

- $\quad$ pocketbook case, covering the front cover and back cover;

- the front of the pocketbook, covering the title of the book, the introduction, the table of contents, and the learning activity;

- the text section of the pocketbook, containing materials and practices; and

- the back of the pocketbook, containing a glossary, table of contents, and Accounting figures.

The Pocketbook is reviewed by the media experts first. The reviewers fill out a review sheet where the contents of the questionnaire are in the form of suggestions and input from media experts in order to find out about the downsides of the Pocketbook as a teaching material. It is revised based on suggestions/feedback from the media experts who produce the revised Pocketbook which subsequently is validated by the media experts to assess its eligibility as teaching material. After the Pocketbook is declared eligible by the media experts, it is tested by XI Social class students.

The results of the recapitulation assessment from the media experts are as follows:
TABLE I. THE RESUlTS OF THE POCKETBOOK RECAPITULATION FROM THE MEDIA EXPERTS

\begin{tabular}{|l|l|l|}
\hline \multicolumn{1}{|c|}{ Media Experts` } & Score Total & Percentage \\
\hline Media Experts`I & 137 & $91.3 \%$ \\
\hline Media Experts` II & 138 & $92.0 \%$ \\
\hline \multicolumn{2}{|c|}{ Average } & $91.67 \%$ \\
\hline Category & Very Eligible \\
\hline
\end{tabular}

Recapitulation of result of expert media appraisal in Table 1 obtained by percentage of media expert's appraisal I 91.33\% with the eligibility criterion of a product which is worthy to be used, media expert II is $92 \%$ with a criterion suitable to be used. The average assessment of media experts obtained $91.67 \%$. Thus it can be concluded that the accounting book based on Problem Based Learning to improve students' learning motivation on accounting subjects class XI from the aspect of the media declared worthy of use and can move on to the next stage. Recapitulation of the validation results of Media Experts can be presented in a bar chart as follows:

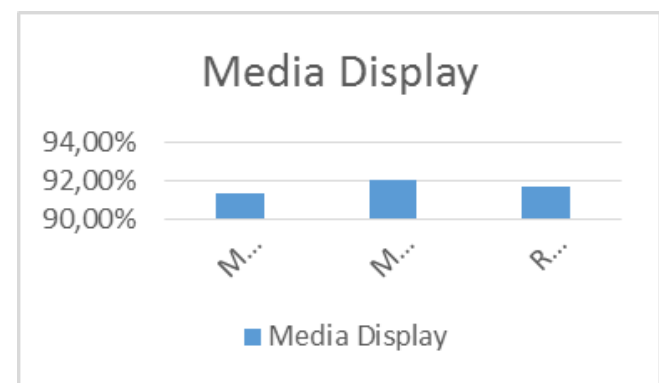

Fig. 1. The Bar Chart of Media Experts’ Validation

TABLE II. THE RESUlTS OF THE POCKETBOOK RECAPITULATION FROM THE MATERIAL EXPERTS

\begin{tabular}{|l|l|l|}
\hline \multicolumn{1}{|c|}{ Media Experts` } & Score Total & Percentage \\
\hline Material Experts`I & 104 & $90.34 \%$ \\
\hline Material Experts`II & 105 & $91.30 \%$ \\
\hline \multicolumn{2}{|c|}{ Average } & $90.87 \%$ \\
\hline Category & Very Eligible \\
\hline
\end{tabular}

Recapitulation of the results of expert media assessment in Table 2 obtained a percentage of expert material assessment I of $90.43 \%$ with eligibility criteria is feasible to be used, material expert II of $91.30 \%$ with eligibility criteria used. The average assessment of media experts obtained $90.87 \%$. Thus it can be concluded that the accounting book based on Problem Based Learning to improve the motivation of high school students from the material aspects declared eligible to be used and tested to the next stage. This can be described using diagrams such as this: 


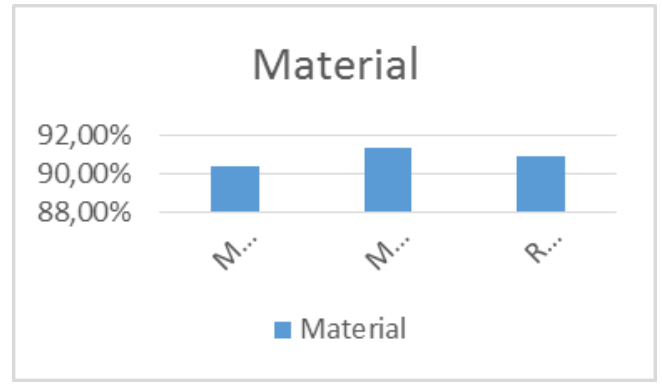

Fig. 2. The Bar Chart of Material Experts’ Validation

\section{Implementation}

After the instrument and pocketbook have been declared eligible to be used by the validators, the next stage is to implement the book in XI Social students at Senior High Schools. The stages done during the implementation stage are, first, introducing the pocketbook to students; second, all 29 students use the pocketbook as an additional supplement in their learning activities; third, the students study together guided by the researchers as their teachers by using the direct learning model; fourth, at the end of the learning process, the researchers give the students a questionnaire of motivation to study after using the teaching material; and last, at the last meeting the researchers conduct an evaluation related to the students' learning results.

\section{E. Evaluation}

An evaluation is carried out in order to reveal the results of students' motivation to study Accounting after using the pocketbook as the teaching material.

- Motivation to Study

After the eligibility of the Accounting pocketbook as a teaching material has been revealed, the increase in students' motivation to learn is measured. The pre-validated questionnaire of learning motivation which has been validated is done prior to the learning process using the Accounting pocketbook as the teaching material. Besides, filling out the final learning motivation questionnaire is done after the learning process is over using the Accounting pocketbook as the teaching material.

Two questionnaires of learning motivation before and after using the pocketbook are compared to reveal the score of the increase of students' motivation to study (learning motivation). The results of the questionnaire of learning motivation of experimental class students after being given treatment with accounting pocketbook based on Problem Based Learning is as follows.
TABLE III. Results of StUdent Motivation Motivation ANALYSis FINAL

\begin{tabular}{|l|c|c|}
\hline \multicolumn{1}{|c|}{$\begin{array}{c}\text { Learning Motivation } \\
\text { Indicators }\end{array}$} & Percentage & Category \\
\hline diligently doing assignments & $78,7 \%$ & Good \\
\hline resilient in facing difficulties & $78,2 \%$ & Good \\
\hline $\begin{array}{l}\text { the emergence of needs and } \\
\text { courage to study }\end{array}$ & $79,0 \%$ & Good \\
\hline $\begin{array}{l}\text { prefers learning } \\
\text { independently }\end{array}$ & $74,4 \%$ & Good \\
\hline easily bored on routine tasks & $79,3 \%$ & Good \\
\hline able to defend opinions & $79,9 \%$ & Good \\
\hline $\begin{array}{l}\text { find it hard to let go of firm } \\
\text { beliefs }\end{array}$ & $79,9 \%$ & Good \\
\hline $\begin{array}{l}\text { the existence of hope and } \\
\text { aspiration in the future }\end{array}$ & $79,6 \%$ & Good \\
\hline
\end{tabular}

Source : The Processed Data of Development Research

The result of the questionnaire analysis of students' learning motivation shows a high percentage of the available aspects to measure learning motivation. So it can be concluded that the learning with accounting pocketbook based Problem Based Learning can provide the impetus necessary to improve student learning motivation in learning activities.

- $\quad$ Final Product Research

Based on what has been carried out development research produces instructional pocketbook material. In the picture below, you will be shown some sample images of the final product that has been researched such as this:

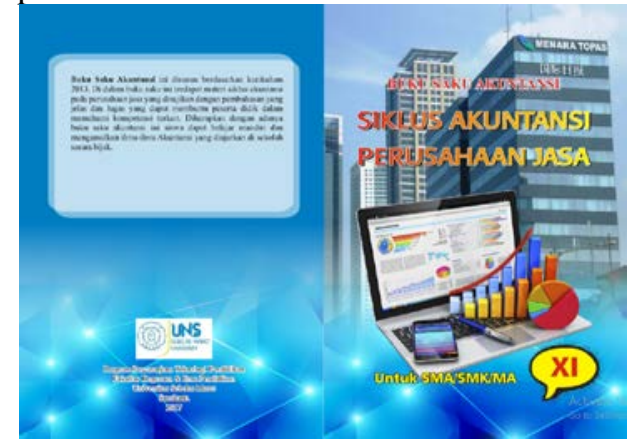

Fig. 3. Model Cover Page

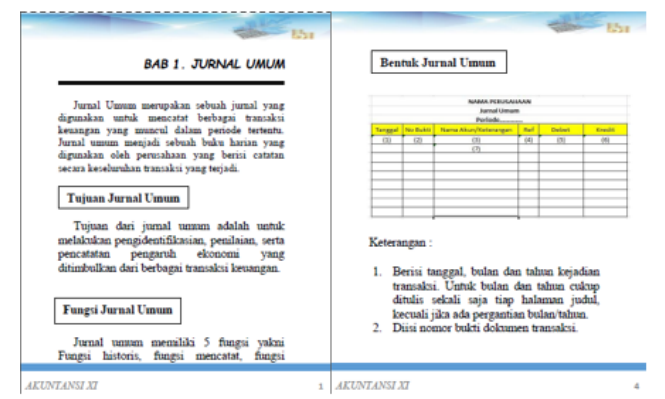

Fig. 4. Example of accounting cycle

The quality of this accounting booklet is included in the "Very Worthy" category. The statement can be proved from the analysis results of the "Very Good" assessment of both the 
expert media experts and material experts, as well as in small group trials and field trials. Learners are happy with this product because they are interested in learning and obtaining new information.

There are some things that in the opinion of learners are seen as an excessive aspect of the product. Among them is an interesting display and the contents of the book is easy to understand. This is in addition to the advantages of this product, as for the disadvantages, including more information from the internet browsing. The existence of some weaknesses, attention and further development efforts can be done by obtaining a better product results. This fact will further open opportunities for further improvement. After going through trial products advantages and disadvantages in the accounting pocket book can then be ascertained.

\section{1) Advantages}

a) A pocketbook can be used as a learning resource with a more appealing look.

b) It can give information to learners.

c) It can help learners in solving problems.

d) Students' knowledge of accounting increases.

2) Weakness

a) The material in the pocketbook is not the work itself but the result of the books trailer and internet browsing.

b) Pocketbook procurement is still relatively expensive in terms of production.

Accounting pocketbooks are designed with interesting concepts and it's easy to understand the material so that students feel interested in learning and we can increase the knowledge of learners. From the results of the analysis of accounting pocketbooks during product trials, we can conclude that benefits for learners and teachers are as follows:

- Learners

- Learners are interested in studying accounting by observing the process of financial records that exist in the pocketbook. Learners become more knowledgeable about the accounting cycle with correct recording.

- The learner's knowledge becomes increased regarding the accounting cycle so that it can be implemented correctly.

- Teachers

- Can be used by the teacher as a learning resource for learners.

- Teachers find it easier to introduce accounting cycles to learners by using the material of the paperback book.

The utilization of pocket accounting materials still has some obstacles. Journal tables that tend to be wide, for example make some learners feel a little bit confused. In the future, the accounting pocketbook is expected to be further refined.

\section{CONCLUSIONS AND SUGGESTIONS}

\section{A. Conclusions}

The conclusions that can be drawn from this research are that 1) The process of developing a pocket book as an Accounting teaching material before passing through the stages of review and validation by was declared eligible to use. It was tested it on 29 XI Social students at Senior High Schools to find out how the pocket book influences the students' motivation to study; 2) The experts declare the pocketbook as an eligible teaching material for XI Social students at Senior High Schools; and 3) there is an increase in students' motivation to study after using the pocket book as the teaching material.

\section{B. Suggestions}

The suggestions that can be drawn based on the conclusions are that 1) The pocketbook as an Accounting teaching material only uses Accounting cycle material, so for further development, it is expected that other materials should be used to provide variation on the Accounting teaching material, 2) Teachers are expected to be more creative and innovative in developing teaching materials that suit the students' needs. It is supposed to create an interesting and fun learning process.

\section{ACKNOWLEDGMENT}

Finally, I would like to thank everyone who contributed to the successful realization of this paper. This paper is far from perfect, but it is expected that it will be useful not only for the researcher, but also for the readers. For this reason, constructive thoughtful suggestions and criticism are welcomed.

\section{REFERENCES}

[1] C. D. Jerald, Defining a 21st century education, 2009. [Online]. Available: www.centerforpubliceducation.org.

[2] Republic of Indonesia, Government Regulation no. 32 year 2013 on amendment to Government Regulation no. 19 year 2005 on National Education Standards, 2013.

[3] H. Uno, Teori Motivasi dan Pengukurannya [Motivation Theory and its Measurement]. Jakarta : Bumi Aksara, 2013.

[4] Ministry of Education, Panduan Pengembangan Bahan Ajar [Teaching Material Development Guidance]. Jakarta: Depdiknas, 2008.

[5] L. L. Hadar, "Opportunities to learn: Mathematics textbooks and students’ achievement,” Stud. in Educ. Eval., vol. 55, pp. 153-166, 2017.

[6] F. N. Khulafa and P. Santosa, "The Development of Pocket Book as Learning Media to Make Batik Jumput in Multicultural Arts and Scarf Subject," 3rd International Conference on Theory \& Practice (ICTP), Adelaide, Australia, 2017.

[7] M. Molenda, "In search of the ellusive ADDIE model," Pervormance improvement, vol. 42, no. 5, pp. 34-36, Submitted for publication in Educational Technologi: An Encyclopedia, A. Kovalchick and K. Dawson, Eds., Santa Barbara, CA: ABC- Clio, 2003. 